\title{
TRANSLATION IN EXILE
}

\begin{abstract}
Arvi Sepp
Vrije Universiteit Brussel/Universiteit Antwerpen. Antwerpen/Brussel, Belgium

Philippe Humblé Vrije Universiteit Brussel. Brussel, Belgium
\end{abstract}

Guillermo Sanz Gallego Universiteit Gent. Gand, Belgique

Désirée Schyns Universiteit Gent. Gand, Belgique

From Ovid over Dante to Victor Hugo, D.H. Lawrence, Thomas Mann, Assia Djebar, Irmgard Keun, Mahmoud Darwish, Salman Rushdie and Julia Kristeva, the experience of exile has profoundly influenced world literature throughout the centuries. For most of these literary émigrés, exile has never merely been a question of location, of being somewhere else, but also of being in a different culture, of which the foreign language is one of the most immediate features. Especially literary exiles experience the problem of the foreign language on a daily and unmediated basis. They are constantly translating or being translated. Their survival, financially and existentially, depends to a great extent on language. ${ }^{1}$

${ }^{1}$ The intricate and indissociable relation between exile and (foreign) language is put forward by Paolo Bartoloni as follows: "But if it is true that it is the subject that moves, it is also true that the abandonment of language is a self-imposed exile, it is a ban that the subject 
Exiled writers can translate themselves, be translated or become translators of other authors' works. Present-day Europe has a number of immigrant writers who publish in the language of their country of adoption, with differing degrees of acceptance of the norms of their new language. Some of them are harassed by authorities, confronted with censorship, excluded from literary institutions, submitted to physical and psychological threats, living in fear of imprisonment. They were forced to leave their homes because of ideological, ethnic, religious, or moral reasons. Others were accused of lack of patriotism in war times or were regarded as depraved by moral conservatives. Already in 1993, Edward Said contended in Culture and Imperialism that liberation as an intellectual mission is very much incarnated by "the intellectual and the artist in exile". He states that the consciousness of liberation represented by those seeking physical sovereignty and intellectual freedom across border is per se political in nature:

Liberation as an intellectual mission, born in the resistance and opposition to the confinements and ravages of imperialism, has now shifted from the settled, established, and domesticated dynamics of culture to its unhoused, decentered, and exilic energies, energies whose incarnation is today the migrant, and whose consciousness is that of the intellectual and the artist in exile, the political figure between domains, between forms, between homes, and between languages. (Said 1993: 332-333)

The translator in exile is also, as Said has it, a "political figure between domains, between forms, between homes, and between languages". Indeed, the émigré translator can become a catalyst in the conceptualisation of alternative worlds by initiating a dialogue

forces upon itself. It is not language that moves away from the subject but the subject that moves away from language." (Bartoloni 2004: 7) On the relation between linguistic and geographical decentering in the exilic experience, see also Mosbahi (1999). 
with the works of world literature. Exiled writers have put to use their knowledge of languages by translating either works of their homeland into their new adopted language, or the other way round. Vladimir Nabokov translated Pushkin, Cabrera Infante translated James Joyce, Pedro Salinas translated Marcel Proust, Hans-Henning Paetzke translated György Konrád, Felix Pollak translated Heinrich Heine. Some of them also translated their own work into their language of adoption: Nabokov translated his early works into English, as did Cabrera Infante.

The selected essays in this issue of Cadernos de Tradução engage with a range of issues relating to 'Translation in Exile'. The papers touch on questions of multilingualism and displacement, and on their methodological implications for translation studies. They consider translating literary texts, first and foremost, as a political and cultural practice. The focus in this issue is on the interlingual nature of translation and exile as an interstitial locus of enunciation. In so doing, these contributions aim at furthering our understanding of the authors' experiences of exile, their function, opportunities and problems as (self-) translators. They explore how these émigrés have documented and represented their own stories. The different papers in this volume also aim at circumnavigating a broad spatial and temporal spectrum, ${ }^{2}$ providing a new understanding of exile as a theoretical concept, analytical category, and lived experience in the study of the translation of literary texts.

The essays in this issue of Cadernos have been divided into four topical areas of inquiry: 1 . Biography of exile; 2 . Poetics of exile; 3. Ontology of exile; 4. Margins of exile. In the first section, the contributions focus on the lives of those translators and writers who were forced by historical or personal circumstances to go into exile, but against all odds continued to translate. The second section deals

${ }^{2}$ We can mention Traduire l'exil - Das Exil übesetzen. Textes, identités et histoire dans l'espace franco-allemand (1933-1945), edited by Michaela Enderle-Ristori (2012) as an example of recent research on translation and exile with a more specific temporal and geopolitical focus (France as a territory of exile to German writers and translators during the Third Reich).

Cad. Trad., Florianópolis, v. 38, $\mathbf{n}^{0}$ 1, p. 10-18, jan-abr, 2018 
with the different ways how writers and translators were affected in their own writing by the experience of exile. Correspondingly, the articles in this section explore how research on writing in exile as well as its objects of inquiry themselves are in continuous flux and have the potential to provide new insights into the intimate relation between literature, translation, and exile. The third section contains two articles concerned with the philosophical foundation of our discussion, pleading for ontological reflexivity, which is posited as an important part of understanding the nexus of translation and exile. Indeed, on an abstract level, they consider translation in itself to be a form of existential and linguistic exile. Finally, in 'Margins of exile' this themed issue wants to shed light on those actors who, not being directly exiles themselves, incorporated aspects of "the condition of the exile" (Nouss 2015) in their work, publishing the texts of exiles or focusing their writing towards the intellectual debate of their original home country.

In "Paul Bowles: Translating from Tangier" Allen Hibbard unravels the complex relationship between the American author Paul Bowles, who lived in Morocco as a self-imposed exile, and the Moroccan authors and storytellers, whose stories were translated by Bowles into English. In so doing, Bowles made this vernacular literature accessible to the rest of the world. By undertaking a nearly anthropological quest, Hibbard clarifies how and why Bowles sought refuge in translation. Hibbard also discusses the features of these oral stories, translated by Bowles despite his lack of proficiency in Arabic. He reveals the postcolonial and Orientalist contexts of this translation process.

In "Traducciones al catalán y exilio franquista", Montserrat Franquesa Gòdia provides a comprehensive chronological overview of Catalan translations, produced and published in exile during Franco's dictatorship. Franquesa's research focuses on four major Catalan translators in exile from three different periods: Jose Carner i Puig-Oriol, Cèsar August Jordana, Agustí Bartra, and Jordi Arbonès. Drawing on Antoni Rovira i Virgili, Franquesa highlights the importance of these exile translators in 
the process of maintaining Catalan cultural identity during the Franco Regime.

Lieve Behiels's article "Rosa Chacel: novelista y traductora española exiliada" undertakes an analysis of the Spanish author's work as a translator in exile, after the Spanish Civil War. After analysing Chacel's proficiency in the source languages of the works which she translated (English, French, Italian, Greek, German and Portuguese), Behiels discusses Chacel's own concept of translation and aesthetics. As a result, she is able to demonstrate how the author's exilic condition had an essential impact on both her translation activity and her style as a translator.

Anne Benteler's contribution explores how German writers, fleeing National Socialism, used translation as an innovative mode of multilingual writing. Benteler's analysis focuses more specifically on the literary writings of German exiles Mascha Kaléko and Werner Lansburgh. She addresses the question if in exile literature translation is an aesthetical technique and if it can reflect the existential and linguistic difficulties of being an exiled writer.

Drawing on theories by Francis R. Jones and Haroldo de Campos, An Van Hecke's contribution "Poesía y traducción en el exilio: La obra de Alaíde Foppa" aspires at exploring the Guatemalan author Alaíde Foppa and her work as a translator of poetry. Van Hecke discusses Foppa's life as an exile in Mexico, and her multifaceted professional career. She subsequently focuses on three different poems translated by Foppa and on a series of paratexts revealing the writer's vision on poetry translation.

Nicoletta Pesaro's contribution explores the novels by Chinese dissident Ma Jian. Pesaro makes plausible how the author, as a representative of the Chinese diaspora, not only lives in a deterritorialized space, but also writes novels that reflect a similar instability on the textual level. Her contribution provides examples of the effects of translation on the process of Ma Jian's transnational reception. In this context, Pesaro investigates the use of the narrative mode in Ma Jian's texts as an allegoric device so as to represent the author's ambiguous cultural and linguistic identity. 
In her article "Self-translation and exile: a study of the Cases of Ngugi Wa Thiong`o and Ariel Dorfman”, Maria Alice Gonçalves Antunes deals with self-translation as a way of surviving in exile. She focuses on Kenyan author Ngugi Wa Thiong'o and on the Chilean-Argentine-American author Ariel Dorfman. Both authors were forced to leave their homeland and to translate their works into and from English. Antunes adapts John Glad's multidimensional model of the process of literary creation of exiled writers in order to provide new paths for research on exile and self-translation, as well as to create a context for the complex activity of self-translation of these authors in the United States.

In "Exil et discours sur la traduction", Winibert Segers and Henri Bloemen contend that the notion of exile is often understood in a subjectified way, centred on authors or translators who find themselves in a situation of exile. In order to substantiate their argument, they analyse the translations of the Catéchisme préparatoire au baptême within the Congolese context. The Catéchisme préparatoire au baptême was translated into several different Congolese languages by Flemish Catholic missionaries in the late nineteenth century and early twentieth century. Segers and Bloemen's contribution closely scrutinizes how the missionaries treated the lexical and metaphorical characteristics of the source text and how their translations functioned within the Congolese cultural context, where the source text is perceived as fundamentally alien. In so doing, Segers and Bloemen reflect more generally on the notion of exile in the discourse on translation.

In "Theses on Pure Language and Postliterate Translation: Walter Benjamin and the Experience of Existential Exile in Language and Translation", Gys-Walt Van Egdom argues that in "The Task of the Translator", Benjamin contends that all languages share one basic characteristic: they all move toward a point of convergence. To designate this point of convergence, Benjamin makes use of the elusive concept of "reine Sprache". In the article, Benjamin's tread is taken up and interwoven with "instances of postliteracy", such as they are found in literature, to form a tapestry depicting 
not only the remembrance, but also the ever-renewing promise of a purified language that constitutes the essence of a metaphysical exile in language. By providing three instances of postliteracy in translation, Van Egdom aims to cast new light on Benjamin's theory of language and translation.

In the "Traduction et exil au XXIème siècle. Pour une poétique collective de la résilience", Ana Paula Coutinho expounds on the significance of the different actors involved in the translation process. She focuses on the status of the editors of exiled authors, who are published despite, on the one hand, the difficult circumstances proper to dictatorship and the unbalanced power relations between major and minor languages, on the other. Coutinho deals more specifically with the Portuguese publishing house "Cavalo de Ferro" that has foreign literature translated by authors in exile. She stresses how this publishing house managed to compete with major publishing houses by giving voice to these authors in Portuguese, a peripheral language. Coutinho thus puts forward the argument that authors in exile need such publishers in order to reach the envisaged readership.

In "L'homme plus que machine (1748): la parole dialogique d'un imprimeur des lumières", Lieve Jooken and Guy Rooryck focus on Elie Luzac. Luzac was a descendant of Huguenots who, being Protestant, were forced to emigrate to the Dutch Republic after the revocation of the Edict of Nantes in 1685. In the Netherlands, Luzac succeeded in developing a successful career as a printerpublisher. Additionally, he played a pivotal, albeit paradoxical, role in disseminating the materialist ideas of La Mettrie's Homme machine (1747). Jooken and Rooryck analyse this discursive ambiguity in Luzac's own text, since the author cites La Mettrie's theses (which he himself had published) in order to criticize them. The authors show how the English translator of Luzac's work eliminates the concealed claims of the original text.

These eleven contributions build a brick-by-brick argument to demonstrate how translation can be used in exile as a means of giving voice to silenced and dissident narratives. They make 
explicit that translation may become a counterbalance, a reaction against propaganda discourses imposed by undemocratic regimes and their compliant publishing houses in the homeland, and also a reaction against or in favor of those narratives politicized and elaborated by dissident émigré presses (cf. e.g. Sanz Gallego 2016, Alemany 2017, Vélez 2017). Providing access to such texts is shown to be a hazardous undertaking, since all actors involved in the translation process - authors, translators and editors alike - put much at risk: their profession, their financial stability and physical integrity. Against this backdrop, the contributions in this special issue offer a window on future avenues of research which the field has yet to offer.

In the book review section, there are three accounts. The first one is on Translation, hypertext, and creativity: A review of Contemporary translation theories (Edwin Gentzler, 2001) by Davi S. Gonçalves. In the second one, Thomas Kelahan discusses a publication by Chan Sin-wai (2017), The Future of Translation Technology: Towards a World without Babel. In the last review, Emily M. Antaya discusses Introduction to Healthcare for Spanishspeaking Interpreters and Translators by I. Crezee, H. Mikkelson and L. Monzon-Storey. As for the translation reviews, there is an account of Hinos Órficos: Perfumes, translated by Ordep Serra, who also wrote the introduction, comments and notes. The discussion of this translation is by Pedro Barbieri. Finally, there is a review of the translation of El juguete rabioso by Roberto Arlt, translated by Davidson de Oliveira Diniz as $A$ Vida Porca. The account is by Cleber Souza Cordeiro. Finally, there is an interview with the Kenyan writer Ngũgĩ wa Thiong'o 


\section{References}

Alemany, Luis. "Ruedo Ibérico manipuló 'La Guerra Civil española' de Hugh Thomas en beneficio de la II República” El Mundo, 15 June 2017a. < http:// www.elmundo.es/cultura/literatura/2017/06/15/59414b34e2704e51488b45da. $\mathrm{html}>$ (accessed 15 June 2017).

Bartoloni, Paolo. "Benjamin, Agamben, and the Paradox of Translation." CLCWeb: Comparative Literature and Culture 6.2 (2004): 1-9. < http://dx.doi. org/10.7771/1481-4374.1231 > (accessed 17 September 2017).

Enderle-Ristori, Michaela. Ed. Traduire l'exil - Das Exil übesetzen. Textes, identités et histoire dans l'espace franco-allemand (1933-1945). Tours: Presses Universitaires François-Rabelais, 2012.

Mosbahi, Hassouna. "Sprache des Exils und Exil der Sprache." Wir und die Anderen. Islam, Literatur und Migration. Eds. Walter Dostal, Helmuth A. Niederle and Karl R. Wernhardt. Vienna: WUV-Universitätsverlag, 1999. 273-277.

Nouss, Alexis: La condition de l'exilé. Penser les migrations contemporaines. Paris: Éditions de la Maison des sciences de l'homme, 2015.

Said, Edward. W.: Culture and Imperialism. London: Vintage, 1993.

Sanz Gallego, Guillermo. La traducción como manipulación historiográfica en el exilio: análisis paratextual e intertextual de La Guerra Civil española de Hugh Thomas. Arbor, 192 (780): a340. 2016.

Vélez, Iván. “Hugh Thomas, Cortés y Lutero.” ABC, 17 July 2017b, p. 15.

Arvi Sepp. E-mail: arvi.sepp@uantwerpen.be / arvi.sepp@vub.be

Philippe Humblé. E-mail: Philippe.Humble@gmail.com

Guillermo Sanz Gallego. E-mail: Guillermo.SanzGallego@ugent.be

Désirée Schyns. E-mail: Desiree.Schyns@ugent.be 